\title{
半導体パッケージプロセスにおける最新露光技術
}

\author{
李 徳*
}

\section{Latest Exposure Technology in Semiconductor Package Process}

Duk LEE*

\footnotetext{
*株式会社オーク製作所装置カンパニー日の出工場光学技術部（† 190-0182 東京都西多摩郡日の出町平井 28-5）

*ORC MANUFACTURING.CO.,LTD. (28-5 Hirai, Hinode-machi, Nishitama-gun, Tokyo 190-0182)
}

\section{1. 半導体パッケージ市場の動向}

\section{1 市場の技術背景}

半導体 LSI，IC の微細化は，その露光技術の限界点を迎 えつつある中において緩やかな鈍化傾向を強めている。か つて提唱されたムーアの法則においての微細化の進化速度 からの遅れは年々顕著となっており，結果的にそれらを補 填する形でパッケージ全体での性能向上策が図られている と言える。この中で，さまざまな新しい手法におけるパッ ケージング技術が提唱・台頭・採用されてきており，昨今 の混沌とした各種技術の乱立に至る一因となっている。

\section{2 市場を牽引する要因}

かつてパッケージ技術といえばMPUをはじめとして演 算処理ユニット周辺技術がその代表例であったと言える が, 現在においては最終カスタマ製品の大きな変化の中 で，その様相は一変している。代表的なものとして，PC 時 代からモバイル時代への移行であろう。高周波数, 高性能 処理能力を達成するために微細化, さらには大電力消費も 厭わなかった時代から，モバイル性能・バッテリ維持能 力・高速デー夕通信などのかつてとは異なる最終製品の評 価視点において, その製品の優劣が判断される時代になっ た。まさに演算ユニットにおける時代の主役は, MPUから $\mathrm{AP}^{\dagger}$ に移行したと言っても過言ではなかろう。

$\mathrm{AP} に$ に代表される省電力な演算ユニット，ならびにサー バー用途の MPU，産業用や高性能な画像処理ユニットであ る GPU の高性能化が進む中, 技術的障壁として大きな課題 となっているのはメモリアクセスの能力と言える。いかに 高速に処理を出来る演算ユニットを有していても, メモリ から送り込むデー夕速度が律速となる状況を迎えつつある からだ。それを解決すべく, 半導体パッケージには高速な メモリアクセス能力が要求されてきており, 従来とは異な る構造の複数手段提唱・採用が有望視されている。

また，モバイル端末内部だけではなく，端末と基地局を 結ぶ通信規格の高速化を欠くことは出来ない。それに対応 する技術が，5G と呼ばれる高周波通信規格である。本通信

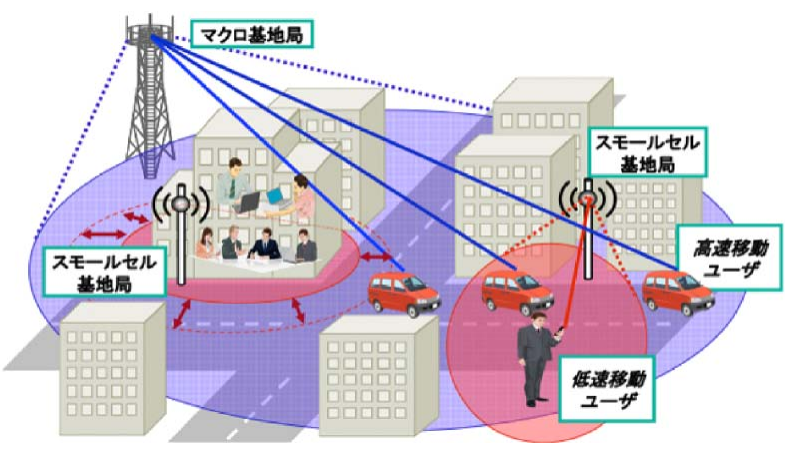

図表 1.5G 世代におけるネットワークモデル ${ }^{1)}$

規格は高周波対応にて高速通信が可能な反面, 電波到達が 短距離化するために基地局が小規模な形で多数配置を要す るスモールセル化が進む公算が高いと言える。つまりは絶 対必要需要が増加することを意味している（図表 1)。

\section{2. 主な半導体パッケージ市場の露光技術}

\subsection{FC-CSP 用途}

当該市場においては， $\mathrm{BGA}$ などの $\mathrm{IC}$ キャリアパッケー ジに比較すると, 早期にダイレクト露光装置が露光方式の 主流となった。ダイレクト露光装置は 2008 年を境に一気に 市場に普及しはじめた新世代の露光装置である。最大のメ リットは, 従来のコンタクト露光装置やステッパ装置に必 要不可欠なマスクが不要であることは言うまでもない。ま た，マスクの代わりとなる仮想原版のデジタル描画データ は，ワークの変形や伸縮の度合いに応じていかようにでも 変形補正をリアルタイムで出来る強みがある。絶縁層工程 に扔いては，このメリットを最大限に生かすことで飛躍的 に Pad-SRO ${ }^{\dagger}$ の位置合わせ精度を劇的に高めた。その反面, 回路形成工程においてはダイレクト露光装置を採用した後 も, パネル全面に対して 4 点一括アライメントにて量産を 行なっていたことも考慮すると，位置合わせ精度だけでは なく, 非接触露光によるパーティクル起因の歩留まり向 上，ならびにマスクレスの工程的なコストメリット，さら には試作や問題発生時・デザイン変更時における対応速度 
の速さが重視されたとも言える。

\subsection{FC-BGA 用途}

当該市場に扔いては, コンタクト露光装置が長らく主力 露光方式として君臨したが, 日本国内のパッケージ最大手 の 2 社がステッパ装置を採用・導入したことから MPUを 代表とするハイエンド製品においてはステッパ装置が主流 の位置を占めている。FC-CSP に比較すると, 比較的単一 製品の製品寿命が長くマスクコストを吸収しやすい点, 2008 年から 2010 年頃の技術ロードマップの観点では FC-CSP よりも微細なデザインルールであり, 解像力に優 れながら生産性も確保しやすいステッパ装置が採用された 点は, 極めて妥当であったと考える。本市場における装置 の特殊性は, 露光面に扔ける口径が $\phi 350 \mathrm{~mm}$ クラスの極め て大きな面積を有する一方, 解像力は $8-12 \mu \mathrm{mL} / \mathrm{S}$ 程度の 投影レンズを有している点であろう。現在同市場における パネルサイズのデファクトスタンダードは $500 \times 500 \mathrm{~mm}$ ク ラスの基板であるが, FC-BGA に要求される配線精度を満 足しつつ, ショット数を減らし生産性を高めるという当該 セグメントに特化した露光装置の形である。本寄稿におい ては, その他ステッパ装置との区分けのために当該装置セ グメントを「ラフレイヤ用ステッパ装置」と呼ぶこととす る。

\subsection{WL-PKG 用途}

前記までの市場は, すべてパネル形状の有機基材がベー ス材料となっているが, WL-PKG 市場のサブストレートは すべて Si ウェハである。また, 当該セグメントの中で製品 がチップダイの大きさに近しい製品を特化してWL-CSP と 呼ばれる。サブストレートが有機基材に比べ $\mathrm{Si}$ ウェハが高 いこと, また感光材もポジ型液体レジストを使用すること から各工程のプロセスコストも高いため, 難度が高い最終 製品に多く採用されるセグメントと言えるであろう。当該 市場においては，ステッパ装置が過去も現在も主力露光方 式として君臨している。前記ラフレイヤ用ステッパ装置と 比較すると, 露光面積は $1 / 30$ 以下であるが, 解像性・位 置合わせ精度ともに 1 桁程度高い精度を達成出来る点が特 徵であろう。また, 長い歴史の中で実績のある液体レジス

図表 2. 各技術トレンドの特徴比較表

\begin{tabular}{l|c|c|c}
\hline \multicolumn{1}{c|}{ 項 } & $\begin{array}{c}\text { ダイレクト } \\
\text { 露光装置 }\end{array}$ & $\begin{array}{c}\text { ラフレイヤ用 } \\
\text { ステッパ装置 }\end{array}$ & ステッパ装置 \\
\hline 解像性能 & $2-10 \mu \mathrm{m} \mathrm{L} / \mathrm{S}$ & $5-10 \mu \mathrm{m} \mathrm{L} / \mathrm{S}$ & $1-3 \mu \mathrm{m} \mathrm{L} / \mathrm{S}$ \\
\hline $\begin{array}{l}\text { 一括露光 } \\
\text { サイズ }\end{array}$ & パネル全面描画 & $\begin{array}{c}150 \times 150 \mathrm{~mm} \\
\text { or } \\
250 \times 250 \mathrm{~mm}\end{array}$ & $\begin{array}{c}52 \times 33 \mathrm{~mm} \\
\text { or } \\
70 \times 70 \mathrm{~mm}\end{array}$ \\
\hline $\begin{array}{l}\text { 位置合わせ } \\
\text { 精度 }\end{array}$ & $\pm 3-5 \mu \mathrm{m}$ & $\pm 3-5 \mu \mathrm{m}$ & $\pm 1 \mu \mathrm{m}$ \\
\hline $\begin{array}{l}\text { 変形機能 } \\
\text { オート }\end{array}$ & 自由変形可能 & $\begin{array}{c}\text { スケーリング } \\
\text { and }\end{array}$ & $\begin{array}{c}\text { 変形無し } \\
\text { or }\end{array}$ \\
\hline $\begin{array}{l}\text { フォーカス } \\
\text { 焦点深度 }\end{array}$ & 以上 500 点 & 独立スケーリング & スケーリング \\
\hline
\end{tabular}

トを使用する製品群も多く，i 線 $(365 \mathrm{~nm})$ だけでなく $\mathrm{g}$ 線 $(436 \mathrm{~nm}) \cdot \mathrm{h}$ 線 $(405 \mathrm{~nm})$ も露光に必要となるため, 投影レ ンズにはマルチウェーブの色収差補正を要求される。この 観点が，半導体 LSI などの最先端スキャナと大きく異なる 点と言えよう。

\section{4 各種露光装置の特徵と比較}

ダイレクト露光装置, ラフレイヤ用ステッパ装置, ス テッパ装置の 3 方式の特徴と相互比較を以下のとおりに定 義した。当社含め, 露光装置メーカ各社におけるさらなる 個別の特徵や特性の差もあることは事実であるが，大きな 意味での比較という観点では認識に相違はないであろう。

前述の通り，各方式にはそれぞれメリット・デメリット を有して扔り，100\% 全ての面に扔いて抜きん出た装置は 存在していない。それが故に，各製品セグメントにおいて 採用されている露光装置が異なる, という結果になってい ると言えよう。

\section{3. 最先端 半導体パッケージの技術要求}

\section{1 新世代を言引する技術トレンド}

\subsubsection{FO-WLP ${ }^{\dagger}$}

2016 年から 2020 年までの期間においては, 20 年に 1 度 の大きな転換期を技術トレンド面で迎える様相を呈してい る。その代表格が FO-WLP であることは誰の目にも明らか だ。従来，有機基材をサブストレートとする FC-CSP が製 品の主力構造として採用されていた分野に，Si ウェ八をサ ブストレートとする新工法 FO-WLP が名乗りを上げたの だ。特にハイエンドの部分に位置する AP は，すでに世界 有数の大手メーカが採用し量産中である。この FO-WLP の 最も技術的な優位性は，そのパッケージ構造の薄さであろ う。高精細なファイン $\mathrm{L} / \mathrm{S}$ を RDL 層 ${ }^{\dagger}$ に配置し配線密度を 向上し，FC-CSP 構造と比較し格段に少ないレイヤ数によ る構造を実現したことでパッケージの総厚が $60 \mu \mathrm{mt}$ 以下の レベルを達成したことは, 当時大きなインパクトを業界に 与えた（図表3）。

3.1.2 有機インターポーザ (2.1D, 2.5D PKG)

MPU や GPU の処理能力の技術的障壁にメモリアクセス があることはすでに記載の通りであるが，本課題を解決す る技術的なアプローチの一つが有機インターポーザであ る。処理プロセッサと HBM などを 2 次元実装するために 必要な本技術は，2020 年までに大きな飛躍を遂げると見ら

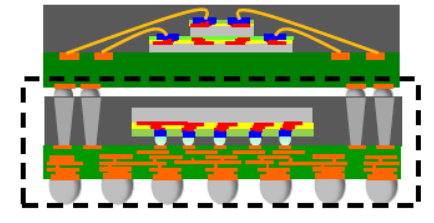

TMV 接続 PoP 構造

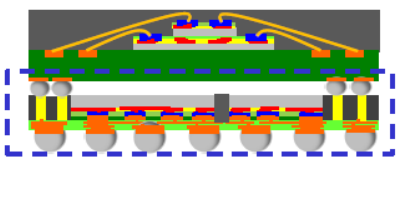

下側 FO-WLP 化 PoP 構造
図表 3. FO-WLP 化による従来技術との構造比較 ${ }^{2)}$ 
れている。本技術要求は, 限りなくWL-PKG の技術と近し い精度達成であり, Si ウェハにて達成していた製品精度を 有機基材のパネルにて達成しなければならないことが最大 のハードルだ。有機基材のパネル工程では従来想定もしな かった微細な配線形成要求, それに伴う層間接続の開口微 小化, それらトータルに影響を受ける各レイヤの位置合わ せ精度向上, そして何よりも Si ウェハに比較し圧倒的に伸 縮, 異形変形, 反りを発生する有機基材特有の課題, それ ら全てが本技術の達成における課題だ（図表 4）。

\subsubsection{FO-PLP $^{\dagger}$}

FO-WLP がSi ウェハをベース材料とする技術ならば, FO-PLP は同技術を用いながらパネルの有機基材をベース 材料とする非常に野心的な技術である。FO-WLP はその構

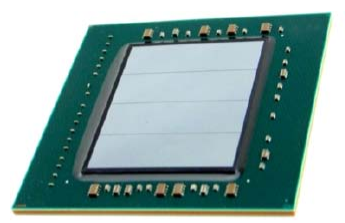

Homogeneous Integration in organic substrate (courtesy of Xilinx)

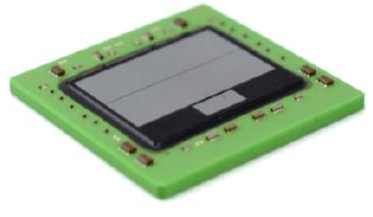

Heterogeneous Integration in ceramic substrate (courtesy of Xilinx)
図表 4. 有機インターポーザの実製品サンプルモデル ${ }^{3)}$
造的なメリットは優れているものの，プロセスコストに大 きな課題を残している。これは Chip First 工法による IC や LSI の破損リスクなどを除いても，工程全体がウェハプロ セスであること，またベース材料のサイズが $\phi 300 \mathrm{~mm}$ で製 品取り数が少ないことが原因であろう。FO-WLP の構造的 なメリットは活かしつつ, これらの課題を解決できること がFO-PLP の最大の特徵である。

しかしながら, 有機インターポーザと同様にパネルの有 機基材特有の問題が大きな課題となり, そのハードルは極 めて高い。歩留まり低下時における Chip First 工法での IC や LSI 破損リスクは事業モデルそのものを脅かす危険性す らある。

\section{1 .4 各技術トレンドの比較}

図表 5 は，各技術セグメントにおける実装技術全体とし ての構造概要図である。この中で有機インターポーザ技術 は，3D IC，3D WLPなど広範な領域を有機パネルにて対応 を目指す技術と位置付けられよう。

前記の大きな技術トレンドを以下の通り，此較・まとめ をした（図表 6）。

各技術における特徴はそれぞれあるが，いずれも共通し ているのは「これらの技術が，従来の製品カテゴリ，工程 カテゴリを破壊」することを必要としている点だ。FO-WLP

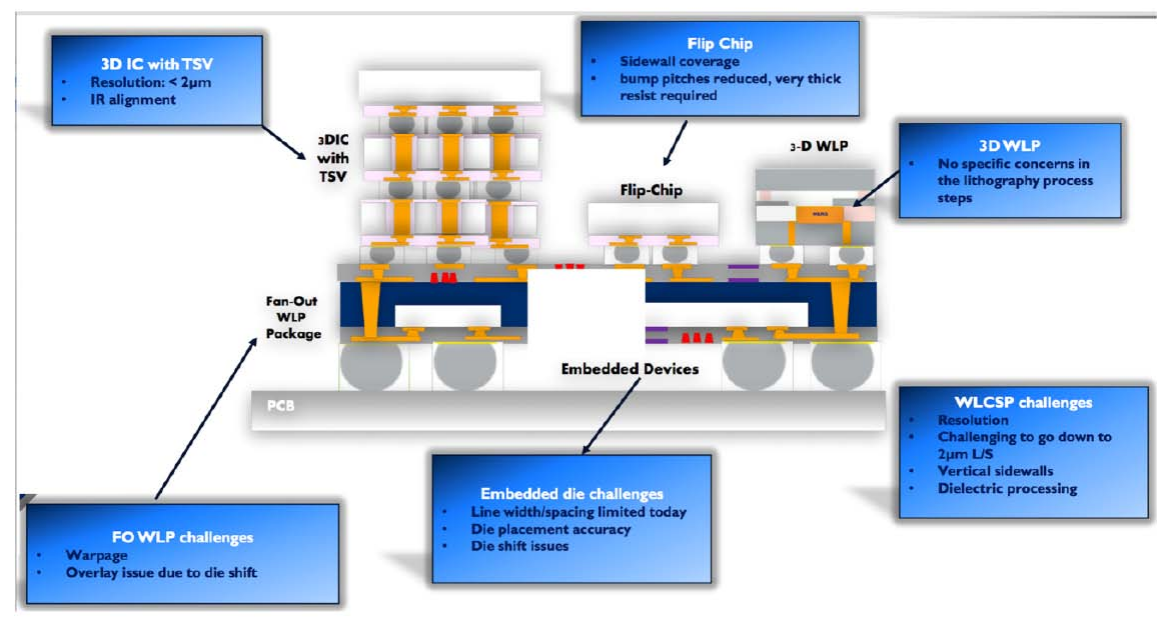

図表 5. 実装技術全容における各技術セグメントの位置付け ${ }^{4)}$

図表 6. 各技術トレンドの特徴比較表

\begin{tabular}{|c|c|c|c|}
\hline 項 目 & FO-WLP & 有機インターポーザ & FO-PLP \\
\hline 用途 & $\mathrm{AP}$ & MPU/GPU & $\begin{array}{c}\mathrm{RF} / \mathrm{PMIC} \\
\text { パワーデバイス }\end{array}$ \\
\hline $\begin{array}{l}\text { パッケージ } \\
\text { サイズ }\end{array}$ & $300-800 \mathrm{~mm}^{2}$ & $1,500-3,000 \mathrm{~mm}^{2}$ & $200-600 \mathrm{~mm}^{2}$ \\
\hline IO Ball 数 & $200 \sim 1,500$ 個 & $500 \sim 3,000$ 個 & $100 \sim 800$ 個 \\
\hline 露光工程 & ステッパ装置 & $\begin{array}{c}\text { ステッパ装置 } \\
\text { or/and } \\
\text { ダイレクト露光装置 }\end{array}$ & $\begin{array}{c}\text { ステッパ装置 } \\
\text { or/and } \\
\text { ダイレクト露光装置 }\end{array}$ \\
\hline 使用感光材料 & ポジ型液体レジスト & $\begin{array}{c}\text { DFR } \\
\text { or/and } \\
\text { ポジ型液体レジスト }\end{array}$ & $\begin{array}{c}\text { DFR } \\
\text { or/and } \\
\text { ポジ型液体レジスト }\end{array}$ \\
\hline サブストレート & $\phi 300$ mm ウェハ & フルパネル有機基材 & フルパネル有機基材 \\
\hline
\end{tabular}


という半導体後工程技術は, 従来 FC-CSP が支配的であっ た製品カテゴリを破壊し，すでに定着・拡大している。ま た，逆に FO-PLP という有機基材べースの技術は半導体後 工程のカテゴリであった WL-CSP が得意している製品カテ ゴリを逆に侵食しつつある。それだけではない。有機イン ターポーザや FO-PLP は, その製造プロセスにおいては従 来の枠を大きく超え, 限りなく半導体後工程のプロセス技 術を採用するであろう。

つまりは，製品も工程も，すべての部分において境目が 希薄になりつつあるのが半導体パッケージ技術の最先端だ と言えよう。

\section{2 露光技術のトレンド}

これら最先端の半導体パッケージ技術から露光装置が要 求されるトレンドは, 何よりもその解像性・位置合わせ精 度を含めたファイン化要求であることは言うまでもない。

\subsection{1 ラフレイヤ用ステッパ装置}

この時点で, 前記 3 方式のうちラフレイヤ用ステッパ装 置については, 当該セグメントに押いてメインストリーム にはなり得ない状況は明確になってきた。最大の課題は解 像性，位置合わせ精度におけるファイン化の限界だ。大面 積を面内で均一に解像性能を得ることは技術的に極めて難 易度が高いからだ。当然生産性を勘案すると大面積一括露 光の魅力は捨てがたいことも事実であり，すでに同装置を 生産ラインで稼働しているメーカにとって他手段の導入 は，すなわち生産性の低下に繋がるジレンマに悩まされて いるであろう。また, 有機インターポーザや FO-PLP に関 してはパネルの凹凸, 反りなど平坦性の問題が非常に大き く, ラフレイヤ用ステッパ装置における最大のメリットで ある大面積一括露光時に面内での焦点深度確保, すなわち 線幅均一性を確保できるかの課題が一層クローズアップさ れることになる。

\section{2 .2 ステッパ装置}

一方，ステッパ装置はすでにFO-WLP, FO-PLP にて生 産寄与することが示されており, 現時点においては露光技 術の主役たる位置に最も近い存在であろう。何よりも他方 式に比べて圧倒的にファイン化が容易なことがその存在感 の後ろ盾だ。また, 現在のこれらの最先端半導体パッケー ジが, FO 技術の中でも前出の Chip First 工法を採用してい ることもその優位性を支えている。RDL 形成時に扔いて, すでに下層にIC が埋め込まれている状態であるが，この害 装精度の問題, また樹脂材の硬化時におけるダイシフトと 呼ばれる IC が XY $\theta$ 方向に位置ずれを起こす問題により埋 め达まれた IC 群は決して整列しているとは言えない状態 だ。そのため, これらに合わせて RDL レイヤを形成するに はそれぞれのICに対しての個別の高精度な位置合わせが要 求される。つまりは, IC 単位に露光を行うことになるわけ であるが，FO-WLP や FO-PLP 技術で製品化を目指す IC や LSI などの半導体 Chip のダイサイズは比較的大きくはな
い。結果, 露光装置に要求される一括露光エリアは最大で も $50 \times 50 \mathrm{~mm}$ 程度だ。これは, ステッパ装置の最大の泣き 所である一括露光面積が小さく, 露光ショット数が増加す るという弱点がデメリットになり得ないということを意味 する。

しかしながら，ステッパ装置にも課題は残る。1つ目は 有機インターポーザにおいては実装される GPU や MPU な どの半導体 Chip 自身のダイサイズが大きいこと，またその 周辺に HBM を 4 個ないし 8 個以上配列する必要性から, ステッパ装置の一括露光エリアでカバーできない製品群が 多数を占めることだ。この場合に押いては，パッケージ全 体を 2 回ないし 4 回の露光にてパターンをつなぎ合わせる スティッチングと呼ばれる技術にて対応をすることにな る。この方法は有効な手段である反面, 露光ショット数の さらなる増大，つなぎ合わせパターンの接続信頼性などの 課題が存在する。2つ目は装置価格が他方式に比べ高い反 面, 生産性が最も劣る点だ。つまり装置 $\mathrm{COO}^{\dagger}$ が低いとい うことに繋がる。量産装置として，この評価点が低いこと は常にメーカを悩ませる大きな課題であろう。

\subsection{3 ダイレクト露光装置}

他 2 方式が抱える課題を原理的に解決できる手段が, ダ イレクト露光装置だ。まず，ラフレイヤ用ステッパで課題 の解像力や位置合わせ精度に抏いて, 最新のダイレクト露 光装置にでは解決の目処が立ちつつある。そして基板の凹 凸や反りについてもステッパ装置では達成しえない，面内 1,000 点を超える多分割での $\mathrm{AF}$ 補正エリアを提供可能だ。 さらには，ステッパ装置に扔ける課題である大ダイサイズ のパッケージに関してもダイレクト露光装置はその制限を 受けることはない。ダイレクト露光装置は，元々パネル全 面を複数のバンドと呼ばれる露光エリア群をつなぎ合わせ て露光を行う方式であり，パッケージサイズをまたぐパ ターン繋ぎ露光においては従来から当然のように対応して きた技術であるからだ。 IC 個別のダイシフトや，パネル起 因の変形などにデー夕変形による高精度位置合わせを行え ることも本方式の極めて有効な技術機能として挙げられる だろう。

他方, 本方式の課題も残る。配線パターンの微細化に伴 い, $\mathrm{CAD}$ データからの変換後の露光データが極めて巨大に なっていることから，データ処理系の速度限界が最大の課 題だ。現状は露光量起因ではなく, デー夕処理系の時間が 生産性律速になっていると言っていいであろう。また，シ ステム全体がステッパ方式に比べると極めて複雑であり， 装置安定性・メンテナンスの煩雑さなど装置の根幹に関わ る部分においてのシステム信頼性が低いことは明白だ。こ れらの大きな課題をいかに克服するかが，今後最先端半導 体パッケージ分野における露光方式の主役になり得るかの 分水嶺と言える。 


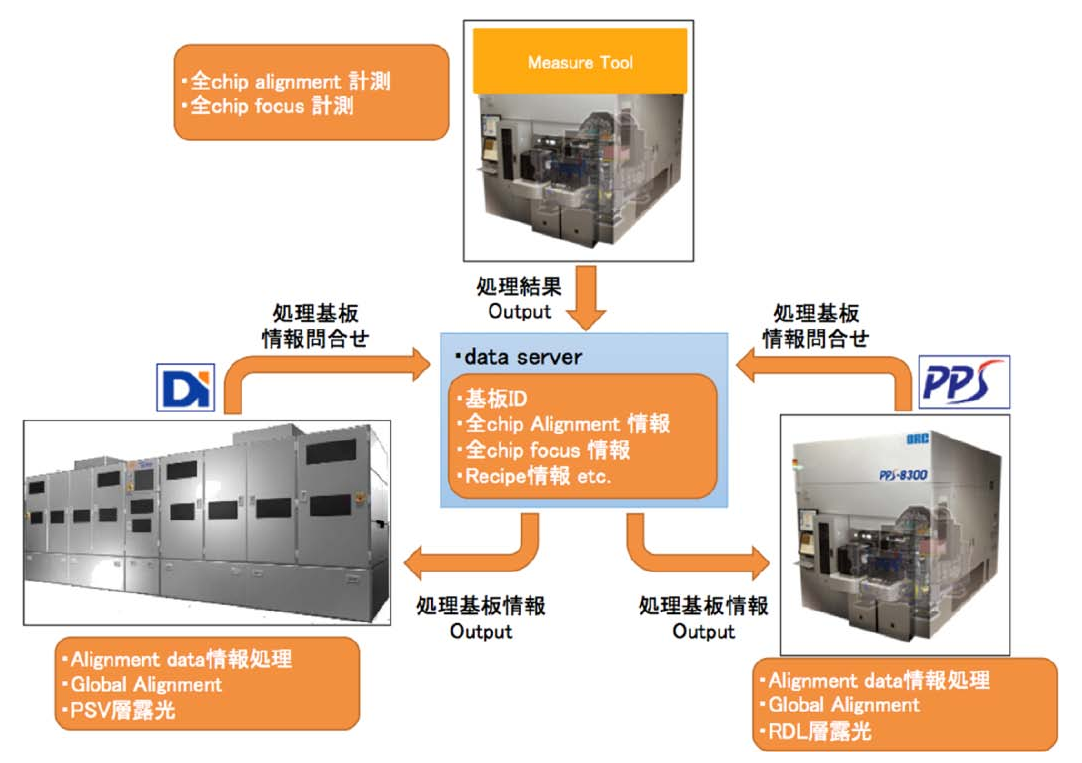

図表 7. 工程の最適化モデルケース

\section{4. 今後の展望}

最先端半導体パッケージにおいては, 10 年に 1 度の大き な転換期を迎えている。半導体後工程技術と有機パッケー ジ技術がマテリアル, 露光方式, 感材, その他プロセス全 般に扔いて境目なくその技術トレンドを検討, 採用をして いると言えよう。その流れは今後加速することは間違い無 く，その中でプロセスの中心たる露光技術に扔いては単一 方式が全アプリケーションに採用される可能性は極めて低 い。その時点で最適な主要性能, 機能面, そして $\mathrm{COO} の$ 観点での判断により, 採用される方式はさまざまなパター ンが存在し得る。そのような複雑な工程が想定される中, 各種装置の有効機能, 長所を相互に活かすためのライン全 体のミックス\&マッチも積極的に検討されていくであろう。

図表 7 に計測ユニット, ダイレクト露光装置, ステッパ 装置を含めた工程の最適化のモデルケースを示す。

ダイレクト露光装置の変形自由度の高さ, ダイバイダイ† 露光時の高速描画性能を活かしながら，ステッパ装置にお けるアライメント時間のデメリットを Measure Toolによる 事前のチップ位置計測にて補完し, 高解像度露光を達成す るモデルケースだ。

今後，露光技術の各方式がそれぞれの弱点をいかに補 い，それぞれの強みをいかに伸ばすかだけでなく，露光技 術のそれぞれの長所を活かし，短所を補完するための工程 構築の多様さは注目に值するであろう。当社ならびに当方 も，この一翼を担うべく露光技術のさらなる発展に向けて 邁進する所存である。

(2018.2.8- 受理)

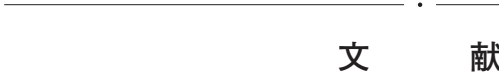

1) Wireless Wire News 2011/2/14 (Wireless Wire News 編集部)

2) TSMC R\&D Release 2014/6 (TSMC)

3) Advanced Heterogeneous Solutions for System Integration 2015 (TSMC Kees Josse)

4) Photolithography for Adv. Packaging, MEMS and LEDs (2015 YOLE 社)

\section{$\dagger$ 用語解説}

AP : アプリケーションプロセッサ。主に，モバイル機器 におけるメイン処理 LSI。

Pad-SRO : パターン層の $\mathrm{Cu}$ パッドと絶縁層の開口部分 のアニュラリング部分。

FO-WLP : ファンアウトウェハレベルパッケージ。

RDL 層：レジストリビューションレイヤー。チップ上に 形成された微細な再配線。

FO-PLP：ファンアウトパネルレベルパッケージ。

COO : コストオブオーナーシップ。装置設備に関して投 資・運営経済性の評価基準をモデル化したもの。 ダイバイダイ：露光されるチップ毎に個別にアライメン トを行う手法

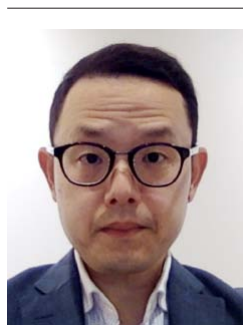

李 徳 $(り-$ とく)

著者紹介 半導体露光装置の光学系開発に従事した後，現 在の（株）オーク製作所にてステッパ開発，ダイ レクト露光装置開発に携わる。現在は光学系に関 する開発業務だけでなく, 装置全体でのプロダク トマネージャーとして開発・技術営業などに従事 している。 